\title{
PERKEMBANGAN KOGNITIF DALAM ISLAM DAN MODEL BIOEKOLOGI URIE BRONFENBRENNER UNTUK HIDUP DI ERA REVOLUSI 4.0
}

\author{
Riki Perdana \\ Ilmu Pendidikan, Program Pascasarjana Universitas Negeri Yogyakarta, Indonesia \\ Email: rikiperdana.2019@student.uny.ac.id
}

\begin{abstract}
Abstrak
Perkembangan manusia dipengaruhi oleh banyak faktor sehingga setiap tahap membutuhkan perlakuan yang berbeda agar dapat menjadi manusia seutuhnya. Penelitian ini bertujuan untuk mendeskripsikan perkembangan manusia model bioekologi dan dihubungkan dengan konsep perkembangan manusia dalam islam. Metode yang dilakukan adalah literature review, dengan merivew sejumlah artikel ilmiah yang terbit sejak tahun 2010 - 2020. Artikel diperoleh dari sejumlah jurnal terindeks seperti google scholar, copernius, scopus Elsevier, Sage publication dan indeks lain. Hasil penelitian menunjukkan bahwa ada lima (5) meliputi mikrosistem, mesosistem, eksosistem, makrosistem dan kronosistem. Terdapat Sembilan (9) tahapan perkembangan manusia mulai dari 0 th hingga 80 th ke atas. Dalam kehidupan di era revolusi industri 4.0 ada beberapa poin yang menjadi prinsip dasar yaitu fleksibilitas, efisiensi, digitalisasi, desentralisasi dan individualisasi kebutuhan. Kesimpulan dari penelitian ini adalah pada setiap perkembangan anak, tidak bisa langsung dijalankan dengan pola revolusi industri 4.0, setiap tahapan memerlukan perlakukan yang berbeda agar pola kehidupan sesuai dengan tuntuan agama Islam tanpa tertinggal dengan arus globalisasi.
\end{abstract}

\section{Key word: Model Bioekologi, Perspektif Islam, Revolusi Industri 4.0}

\begin{abstract}
Abstrack
Human development is influenced by many factors so that each stage requires different treatment in order to become fully human. This study aims to describe the human development of the bioecological model and be related to the concept of human development in Islam. The method used is literature review, by reviewing a number of scientific articles published from 2010 - 2020. Articles obtained from a number of indexed journals such as Google Scholar, Copernius, Scopus Elsevier, Sage publication and other indexes. The results showed that there were five (5) stages of human development in the bioecological model including microsystems, mesosystems, ecosystems, macrosystems and chronosystems. There are nine (9) stages of human development in an Islamic perspective ranging from 0 years to 80 years and above. In life in the era of the industrial revolution 4.0 there are several points that become basic principles such as flexibility, efficiency, digitalization, decentralization and individualization of needs. The conclusion of this research is that for every child development, it cannot be carried out directly with the pattern of the industrial revolution 4.0, each stage requires a different treatment so that the pattern of life in accordance with the Islamic religious guidance without lagging with the current of globalization.
\end{abstract}

Key word: Bioecology Model, Islamic Perspective, Industrial Revolution 4.0 


\section{PENDAHULUAN}

Salah satu teori paling awal dari ekologi pembelajaran telah disampaikan oleh Urie Bronfenbrenner, Ecology Model of Human Development telah menjadi salah satu teori yang paling banyak dijadikan referensi dalam perkembangan anak (O’Toole, Hayes, \& Halpenny, 2019). Dalam tulisantulisannya yang kemudian, Bronfenbrenner merevisi teori ekologisnya, menghasilkan model bioekologis yang memberikan keunggulan pada proses proksimal dan hubungan antara konteks dan karakteristik individu (Ashiabi \& O'Neal, 2015). Pengembangan teoritis penting pertama setelah publikasi model tersebut tersebut adalah pengenalan perbedaan kritis antara lingkungan dan proses perkembangan manusia (Morales, da Agra, \& Matsuno, 2019). Dengan kata lain, pandangan Urie Bronfenbrenner ini memberikan gambaran dasar tentang bagaiamana perkembangan manusia terjadi.

Teori bioekologi Urie Bronfenbrenner memberikan kerangka kerja yang komprehensif untuk memeriksa perkembangan manusia dalam kaitannya dengan individu yang sedang berkembang dan faktor-faktor kontekstual dan ekologis yang memengaruhi kapasitasnya untuk berubah (Lee \& Martinek, 2013). Bronfenbrenner menggambarkan teori perkembangan manusia ini sejak awal sebagai individu berkembang yang mempengaruhi dan dipengaruhi oleh lingkungan (Rosa \& Tudge, 2013). Saat ini manusia telah berada di era industri $4.0 \mathrm{di}$ mana lingkungan berubah dengan sangat cepat. Perubahan lingkungan ini mendasari peneliti untuk mengkaji perkembangan manusia tanpa melupakan dasar dalam beragama.

Sebagai seorang muslim kita harus sadar bahwa agama islam telah menjelaskan konsep perkembangan manusia (Shokhibul Arifin, 2016). Islam tidak hanya agama yang mengatur doa, ibadah, dan ritual, tetapi juga merupakan cara hidup menyangkut setiap segi keberadaan individu, kelompok, dan masyarakat. Sebagai bagian dari tujuan pesannya, Islam memandang manusia yang sedang berkembang sebagai salah satu nilai moral tertinggi (Hassi, 2012). Perkembangan individu atau manusia juga perlu dipandang dari sudut Islam karena agama ini berupaya membangun keseimbangan antara lingkungan dan kondisi social (Ahmad, Bhatti, \& Arshad, 2013). Bahkan, Islam memiliki model komprehensif pengembangan manusia yang meliputi 
pengembangan moral, etika, intelektual dan fisik bersamaan dengan pengembangan keterampilan dan keahlian (Abdullah, 2012).

Oleh sebab itu, dengan mempelajari konsep islam lebih mendalam tentang perkembangan manusia berpotensi memperbaiki kondisi social masyarakat.

Tokoh islam, Imam al-Ghazali telah membahas beberapa variabel kognitif lain yang mencakup kesenjangan intelektual di antara individu dan faktor-faktor yang mempengaruhi perkembangan intelektual dan juga menentukan perbedaan individu dalam kecerdasan (Shehu, 2015). Dengan demikian, model perkembangan manusia harus ditelaah lebih detail secara bersamaan dalam pandangan islam di era revolusi industri 4.0 ini. Selain itu, Islam juga fleksibel dan dapat diterapkan di lingkungan yang terus berubah (Al-Qaradawi, 1985). Ajaran Islam bisa sangat berpengaruh dalam membentuk lingkungan kerja yang menyenangkan karena pusat perhatian dalam Islam dan perkembangan sumber daya manusia adalah manusia, karena Al Qur'an diturunkan sebagai pedoman bagi umat manusia (Razimi, Noor, \& Daud, 2014). Dengan demikian mengkaji Islam untuk mencitakan lingkungan yang baik di era revolusi industri ini menjadi sangat dibutuhkan.

Perkembangan zaman di era revolusi 4.0 berpotensi mengganggu kestablian manusia. Hal ini karena manusia tidak serta merta "kebal" (Sivathanu \& Pillai, 2018) menghadapi perkembangan arus informasi yang sangat cepat. Dalam Industrie 4.0, peran utama manusia bergeser dari operator mesin menuju pembuat keputusan strategis dan pemecah masalah yang fleksibel (Hermann, Pentek, \& Otto, 2016). Selain itu, menurut para ahli dari industri dan penelitian, revolusi industri yang akan datang akan dipicu oleh Internet, yang memungkinkan komunikasi antara manusia dan mesin di Cyber-PhysicalSystems (CPS) di seluruh jaringan besar (Keller, Rosenberg, Brettel, \& Friederichsen, 2014). Dengan demikian, era revolusi selanjutnya membutuhkan teori dasar yang membentengi manusia dalam berkembang di dunia revolusi 4.0 ini.

Konsep kehidupan manusia di revolusi 4.0 telah mengalami pergerseran dari revolusi sebelumnya. Pengembangan Industry 4.0 akan disertai dengan perubahan tugas dan tuntutan bagi manusia dalam dunia industri (Gorecky, Schmitt, Loskyll, \& Zühlke, 2014). Di era ini terjadi adaptasi 
dengan kebutuhan manusia di mana sistem manufaktur baru harus dirancang untuk mengikuti kebutuhan manusia, bukan sebaliknya (Lasi, Fettke, Kemper, Feld, \& Hoffmann, 2014).

Berdasarkan pemaparan yang telah dijelaskan, maka rumusan masalah dalam penelitian ini adalah:

1) Bagaiamana konsep perkembangan manusia dalam islam?

2) Bagaiamana konsep model bioekological dari perkembangan manusia menurut Urie Bronfenronni?

3) Bagaiamana karakteristik kehidupan manusia di era revolusi 4.0?

4) Bagaimana konsep perkembangan manusia model bioekologi di era revolusi 4.0 dalam pandangan islam?

\section{METODE}

Penelitian ini merupakan studi literature dengan mengkaji sejumlah artikel, baik artikel nasional maupun artikel internasional yang terbit pada tahun 2010 2019. Artikel diperoleh dari website google scholar dan aplikasi mendeley. Artikel yang dikaji berdasarkan tiga variabel utama, meliputi model bio-ekologikal dari perkembangan manusia, konsep perkembangan manusia dalam islam dan karakteristik revolusi industri 4.0.

\section{HASIL DAN PEMBAHASAN}

\section{Konsep Perkembangan Manusia Model Bioekologikal}

Dalam model bioekologi, efek kontekstual terbagi dalam interaksi yang kompleks dari mikro, meso-, exo-, dan sistem makro. Cara sistem ini saling terkait dan memengaruhi dapat dipahami pada pemahaman tentang "guncangan" pada sistem makro, seperti keuangan, dapat meningkatkan proses perkembangan saat ditransmisikan ke berbagai kondisi dalam sistem mikro anak. Status sosial ekonomi rumah tangga, Lingkungan tempat tinggal, dan sekolah, akan menentukan kualitas, frekuensi, dan intensitas proses proksimal. Misalnya, ada banyak literatur yang melihat bagaimana kemiskinan dan masalah rumah tangga mempengaruhi perkembangan anak (lihat, misalnya, Duncan \& Brooks-Gunn, 1997).

Aspek Lingkungan dan komunitas serta pengaruhnya terhadap anak-anak juga telah menentang luas (lihat, misalnya, BrooksGunn, Duncan, \& Aber, 1997). Misalnya, status sosial ekonomi keluarga berkorelasi dengan kesejahteraan dan perkembangan 
manusia, tidak jelas apakah status sosial ekonomi menyebabkan variasi dalam kesehatan dan kesejahteraan atau karakteristik pribadi dan individu yang mempengaruhi status sosial ekonomi dan masa depan sosial ekonomi dengan baik (Conger, Conger, \& Martin, 2010, hlm. 687; Mayer, 1997). Selain itu, penelitian telah mulai mengungkap alur mana saja yang mempengaruhi perkembangan anak dan remaja, mulai dari saat perawatan prenatal (saat dikandungan) dan perinatal (5 bulan) yang berkualitas, membahas dialog seperti investasi, meningkatkan stimulasi kognitif di rumah, pendidikan yang keras dan tidak konsisten, merawat anak, kualitas guru yang lebih rendah (McLoyd, 1998).

Berbagai penelitian telah membandingkan implikasi dari kekurangan sementara dengan "kronis" dan bagaimana berdampak pada yang berbeda sesuai dengan kehidupan anak yang sedang berkembang (lihat, untuk akun, Penatua, 1999; McLoyd, 1998; McLoyd et al., 2009). Dengan kata lain, penurunan sementara dalam status sosial ekonomi selama krisis perlu memiliki jangka panjang yang sangat berbeda tergantung pada usia anak.

Mesosystem, menurut Bronfenbrenner, "terdiri dari hubungan dan proses yang terjadi antara dua atau lebih keadaan yang dialami anak yang sedang berkembang" (1994b, hal. 40), seperti hubungan antara rumah dan sekolah. Ia mencatat bahwa "hal itu terbentuk atau diperluas, kapan saja orang yang berkembang pindah ke lingkungan baru "(1979, hlm. 25). Perbedaan utama antara meso dan mikrosistem adalah bahwa dalam kegiatan mikrosistem, peran sosial, dan hubungan antarpribadi terbatas pada satu kondisi, sedangkan mesosystem menggabungkan interaksi, setidaknya dua kondisi (Bronfenbrenner, 1979, hal. 209).

Mesosystem disusun oleh lembagalembaga yang menerima begitu saja aturan interaksi dan membentuk perilaku yang diharapkan dengan bantuan norma-norma bersama. Lembaga tersebut mungkin saling memperkuat atau melemahkan satu sama lain, seperti ketika terdapat aturan implisit untuk mendapatkan status di antara teman sebaya, namun bertentangan dengan standar perilaku yang dinilai oleh sekolah dan dengan aturan yang memfasilitasi hasil belajar (Carter, 2007; Warikoo, 2010).

Situasi dalam mesosystem dapat meningkatkan (atau mengurangi) potensi perkembangan anak ketika (1) transisi dilakukan bersama dengan kelompok/orang lain yang telah terlibat dalam suasana sebelumnya (misalnya, transisi dengan sekelompok teman dari TK ke sekolah); (2) 
ketika peran dan kegiatan antara dua keadaan kompatibel (atau tidak kompatibel) dan mendorong (atau mengecilkan) kepercayaan, orientasi positif, dan fokus pada tujuan, serta keseimbangan kekuatan yang mendukung orang yang sedang berkembang; (3) ketika jumlah keadaan yang berbeda secara struktural ditingkatkan (atau dikurangi) dan yang lainnya lebih (atau kurang) matang atau berpengalaman; (4) ketika konteks budaya atau subkultur berbeda satu sama lain (Bronfenbrenner, 1979, hlm. 209-223).

Exosistem mengacu pada "hubungan dan proses yang terjadi antara dua keadaan atau lebih, setidaknya satu di antaranya tidak terdapat orang berkembang, tetapi di mana peristiwa terjadi yang secara tidak langsung mempengaruhi proses dalam keadaan langsung di mana orang berkembang tinggal" ( Bronfenbrenner, 1994b, p. 40). Contoh dari ekosistem seperti itu adalah tempat kerja orang tua, di mana anak tidak berinteraksi secara langsung, tetapi yang secara tidak langsung, jika orang tua mengalami stress karena pekerjaan, kehilangan pekerjaan, atau sejenisnya, mempengaruhi dinamika keluarga dan dengan demikian mempengaruhi perkembangan anak. Akibatnya, urutan sebab akibat minimal berasal dari dua keadaan agar memenuhi syarat sebagai suatu ekosistem.
Penelitian sampai saat ini telah berfokus pada tiga exosistem yang menonjol yang secara khusus cenderung memengaruhi proses perkembangan anak-anak dan remaja melalui pengaruhnya terhadap keluarga, sekolah, dan teman sebaya: tempat kerja orang tua, jaringan sosial keluarga, dan konteks lingkungan masyarakat (Bronfenbrenner, 1994b).

Penelitian Kohn (lihat, misalnya, Pearlin \& Kohn, 2009) menunjukkan bahwa kepercayaan, standar, dan harapan yang dihadapi orang tua di tempat kerja, misalnya mengenai otonomi atau ketergantungan mereka, adalah apa yang mereka bawa pulang dan pada dasarnya berharap sama dari anak mereka. Akibatnya, orang tua yang selalu tenang di tempat kerja memiliki kecenderungan untuk menundukkan anakanak mereka. Faktor ini dapat membantu menjelaskan transfer nilai antargenerasi.

Guncangan ekonomi dapat memiliki efek luar biasa pada ekosistem. Hal yang memengaruhi tersebut, tidak hanya tempat kerja orang tua tetapi juga situasi mereka yang tidak memiliki pekerjaan. Beberapa fungsi pekerjaan (seperti organisasi saat ini, pendapatan, dan status sosial, dll) dapat dipengaruhi. 
Sistem makro merupakan "pola menyeluruh karakteristik mikro, meso, dan ekosistem dari budaya atau subkultur tertentu, dengan referensi khusus ke sistem kepercayaan, badan pengetahuan, sumber daya material, adat istiadat, gaya hidup, struktur peluang, bahaya, dan siklus pilihan hidup yang tertanam dalam masing-masing sistem yang lebih luas ini "(Bronfenbrenner, 1994b, hlm. 40). Ini termasuk hukum dan peraturan, ekonomi politik, pasar ekonomi, dan kebijakan publik dari masyarakat di mana orang yang sedang berkembang itu berada.

Yang menarik adalah aspek dinamis dari "transisi ekologis," seperti penelitian tentang bagaimana perubahan sosial dan ekonomi mempengaruhi perkembangan anak-anak dan remaja dan bagaimana mereka beradaptasi dengan perubahan seperti itu dalam sistem makro. Yang menarik adalah aspek dinamis dari "transisi ekologis," seperti investigasi tentang bagaimana perubahan sosial dan ekonomi mempengaruhi perkembangan anak-anak dan remaja dan bagaimana mereka beradaptasi dengan perubahan seperti itu dalam sistem makro.

Sementara Bronfenbrenner merujuk pada aspek budaya dari sistem makro, kerangka kerja budaya, politik, dan lembaga masyarakat semuanya saling terkait erat dan saling menguatkan. Dengan demikian, proses perubahan dapat dilakukan melalui beberapa saluran atau entitas, yang hasilnya akan menjadi "seperangkat pola, proses, dan hubungan fisik dan sosial yang rumit \& saling terkait" (Martin, McCann, \& Purcell, 2003, hal. 114 ).

Dengan kata lain, sistem makro dapat diartikan sebagai "ruang" yang menurut Lefebvre (1991) didefinisikan sebagai "produk sosial yang tak terhindarkan dihasilkan dari gabungan aspek huku, politik, ekonomi, struktur dan budaya sosial" (hal. 190). Individu menggunakan alat-alat budaya yang tersedia di lingkungan mereka, atau memilih untuk memahami tantangan serta memilih solusi yang efektif. Mereka juga menemukan strategi untuk memecahkan masalah dengan mengamati perilaku orangorang di sekitar mereka dan konsekuensi dari tindakan mereka.

Model bioekologi cukup fleksibel untuk mengakomodasi variasi lintas-nasional dalam nilai tertentu yang diberikan untuk berbagai aspek perkembangan manusia yang dipengaruhi oleh budaya lokal (misalnya, semakin besar penekanan pada harga diri, aktualisasi diri, dan karakteristik individualisasi dari bagian negara tertentu. kelas menengah; lihat Markus, 2004). Ini 
juga mempertimbangkan kondisi meso dan makrolevel untuk pengembangan manusia secara bersamaan, termasuk menyebarkan mitos dan dongeng yang menopang diri dan kemampuan individu (lihat, misalnya, Hall \& Lamont, 2009).

Demikian pula, model bioekologi mampu menangkap "pengalaman." Proses proksimal dan interaksi lainnya "dialami oleh orang yang sedang berkembang," yang dimaksudkan untuk menunjukkan, "bahwa secara ilmiah terdapat beberapa hal yang sesuai dari lingkungan apa pun tidak hanya mencakup sifat-sifat objektifnya tetapi juga cara di mana sifat-sifat ini dirasakan oleh orang-orang di lingkungan itu "(Bronfenbrenner, 1979, hlm. 22).

Pengalaman dalam pengertian ini adalah konstruksi individu (dan kelompok) dari "tujuan," yang menentukan kapasitas individu (dan kelompok) untuk membuat makna dan representasi diri (Hall \& Lamont, 2009). Pengalaman, sebagian ditentukan oleh kepribadian individu, tertanam dalam budaya dan kebiasaan setempat; dengan demikian, memahami kerangka budaya dan narasi yang membentuk hubungan dan proses di dalam dan di antara keadaan dan sistem sangat penting untuk mengenali faktor-faktor yang meningkatkan atau melemahkan proses perkembangan. Salah satu contoh variabilitas budaya atau kontekstual dalam makna pengalaman berasal dari literatur empiris tentang pengaruh gaya asuh anak terhadap perkembangan kompetensi akademik dan sosial-emosional anak-anak.

Penelitian terdahulu menunjukkan bahwa pola asuh otoritatif (yang menggabungkan kehangatan dengan ketegasan) meningkatkan kompetensi anak yang lebih besar daripada pola asuh otoriter (kehangatan rendah, ketegasan sangat tinggi) atau laissez-faire (kehangatan rendah, kontrol rendah) (untuk ulasan, lihat Baumrind, 1989, 1991). Tetapi penelitian selanjutnya mengamati perbedaan ras, etnis, dan lingkungan dalam pengaruh gaya pengasuhan terhadap kompetensi anak.

Dalam sampel orang tua AfrikaAmerika dan Amerika latin yang tinggal di lingkungan dalam kota yang "berbahaya", perilaku pengasuhan yang otoriter menghasilkan kenakalan remaja yang lebih sedikit daripada perilaku pengasuhan yang otoritatif (Florsheim, Tolan, \& GormanSmith, 1996). Pola temuan ini telah membuat prilaku perkembangan anak mengarah pada pengasuhan "kontrol tinggi" memiliki nilai adaptif yang lebih besar di lingkungan yang lebih berbahaya dan dapat "dialami" oleh anak-anak dengan cara yang berbeda dalam 
konteks tersebut (Furstenberg et al., 1999; Garcia- Coll et al., 1996; McLoyd, 1990; Rodriguez \& Walden, 2010).

Akhirnya, berkaitan konteks perkembangan anak, sudah banyak teori, pengukuran, dan model matematika yang tersedia untuk memungkinkan studi empiris tentang perkembangan anak dan remaja. Seperti yang ditunjukkan sebelumnya, anakanak dan remaja tertanam dalam hubungan satu sama lain di seluruh konteks. Konsekuensinya, studi tentang pengaruh teman sebaya dan efek lainnya dalam ilmu perkembangan manusia telah berkembang, seperti halnya dalam ilmu sosial, meskipun banyak dari studi ini tidak secara meyakinkan mengontrol apa yang menentukan individu berinteraksi dengan yang lain. Kemajuan ini secara langsung sesuai dalam meningkatkan pemahaman kita tentang dampak guncangan ekonomi terhadap perkembangan anak dan remaja.

Akibat dari proses perkembangan manusia bergantung pada sumber daya yang tersedia, nilai, kebijakan, dan pilihan orang tua dalam mendidik anak-anak mereka. Dari perspektif pembangunan manusia, jika kita ingin sepenuhnya memahami efek dari guncangan ekonomi pada perkembangan anak dan remaja, kita harus melacak pengaruh guncangan ekonomi (makro) pada exo sistem dan mesosistem dan pada konteks sistem mikro anak-anak serta proses proksimal (yaitu, interaksi timbal balik antara anak-anak dan lingkungan dekat mereka) yang merupakan pendorong perkembangan manusia.

\section{Konsep Perkembangan Kognitif dalam Pandangan Islam}

Tahapan perkembangan kognitif manusia dalam pandangan islam seperti yang tersirat oleh ayat-ayat berikut sangat terkait dengan tahapan perkembangan fisik mereka. Tahapan tersebut disajikan sebagai berikut oleh Shehu (2015):

\section{Tahap Satu: Periode Persepsi Sensorik (Dari Lahir hingga 2 tahun)}

Ini adalah tahap pertama kehidupan pasca-kelahiran. Tahap ini ditandai oleh persepsi indera melalui lima organ indera, yang mengirimkan informasi ke pikiran. Karena dapat disimpulkan dari ayat-ayat AlQur'an yang mendalilkan tahap ini, pikiran pada periode awal tahap ini kosong atau seperti tabula rasa. Pikiran kemudian menafsirkan dan menyimpan informasi berdasarkan pengalaman dan kedewasaannya yang terbatas. Perilaku pada tahap ini pada prinsipnya ditandai oleh kecenderungan refleksif dan instingtif yang bersifat bawaan lahir dan bawaan (specie-behaviour). 
Dengan interaksi terus-menerus dengan lingkungan, kecenderungan ini memudar secara bertahap dan digantikan oleh perilaku sukarela. Ayat yang menunjukkan tahap perkembangan kognitif ini berbunyi:

Dan Allah mengeluarkan kamu dari perut ibumu dalam keadaan tidak mengetahui sesuatupun, dan Dia memberi kamu pendengaran, penglihatan dan hati, agar kamu bersyukur (An - Nahl: 78).

Ini adalah tahapan yang Piaget disebut tahapan motorik sensorik. Dalam ayat di atas, Al-Qur'an telah menyinggung sifat sensori dari perilaku anak, 14 abad sebelum Piaget muncul.

\section{Tahap Dua: Anak usia dini (Dari 2-7 tahun)}

Tahap ini disampaikan oleh banyak ayat. Misalnya ayat 5 Surah An - Nisa yang berbunyi:

Dan janganlah kamu serahkan kepada orang-orang yang belum sempurna akalnya, harta (mereka yang ada dalam kekuasaanmu) yang dijadikan Allah sebagai pokok kehidupan. Berilah mereka belanja dan pakaian (dari hasil harta itu) dan ucapkanlah kepada mereka kata-kata yang baik.

Ungkapan, “orang-orang yang lemah dalam pemahaman" telah ditafsirkan oleh para ahli seperti Ibn Abbas. Dasar penentuan batas usia naik dari tahap ini pada usia tujuh (7) tahun adalah Hadis di mana Nabi (SAW) memerintahkan bahwa anak-anak pada usia tujuh tahun harus diperintahkan untuk sholat. Hadits ini menunjukkan bahwa dengan memasuki usia 7 tahun, anak telah menyelesaikan satu tahap pertumbuhan mentalnya dan karena itu pindah ke tahap lain.

\section{Tahap Tiga: (Periode Penegasan atau Masa Kecil) (Dari 7-10 tahun)}

Tahap ini dibatasi oleh Hadis Nabi (SAW) yang sebagiannya telah dikutip di atas. Dalam Hadits, Nabi (SAW) mengatakan anak-anak harus dicambuk karena meninggalkan shalat pada usia sepuluh tahun. Hadits ini benar-benar menunjukkan periode perkembangan mental yang sepenuhnya eksklusif. Ini menyiratkan bahwa pada usia tujuh tahun anak mulai memahami apa yang pantas dilakukan. Pada usia 10 tahun kemampuan untuk membedakan telah memperoleh kualitas yang signifikan sehingga anak itu bahkan 
dapat dihukum karena meninggalkan apa yang pantas dilakukan.

\section{Tahap Empat: Periode Remaja Awal (Dari 10 - 15 tahun)}

Ini adalah periode di mana perkembangan kognitif individu mulai menganggap tren formal. Dasar pemikiran abstrak mulai diletakkan di sini. Dalam periode ini individu masih tetap berada dalam domain mentalitas masa kanak-kanak. Tingkat perkembangan intelektualnya belum memiliki status kedewasaan. Itulah sebabnya dalam pengertian Islam; anak individu pada tahap ini belum menjadi mukallaf (mayoritas orang yang bisa bertanggung jawab atas semua tindakannya). Dasar dari pandangan ini adalah Hadis Rasulullah yang dikutip

Pena (untuk catatan dosa) ditangguhkan (dari mencatat dosa) terhadap anak kecil sampai ia mencapai kedewasaan, gila sampai ia mendapatkan kembali kewarasan; dan tidur sampai dia bangun.

\section{Tahap Lima: (Zaman Pubertas - Zaman} Penuh) (Dari 15 -33 tahun)

Usia pubertas adalah titik balik dalam perkembangan fisik dan kognitif anak. Anak individu diasumsikan telah mencapai status perkembangan kognitif dewasa sejak usia pubertas. Itulah sebabnya semua kewajiban menjadi kewajibannya secara otomatis saat dia memasuki usia puber. Dia sekarang bertanggung jawab atas semua tindakan dan perbuatannya. Itu sebabnya jika dia melakukan dosa, itu sekarang akan dicatat melawannya. Hadits yang baru saja dikutip di atas mendukung penjelasan ini. Beberapa ayat yang dikutip juga menegaskan hal ini. Misalnya Surah An Nisa (4): 6 sebagai berikut:

Dan ujilah anak yatim itu sampai mereka cukup umur untuk kawin. Kemudian jika menurut pendapatmu mereka telah cerdas (pandai memelihara harta), maka serahkanlah kepada mereka harta-hartanya.

Tahap Enam: Periode Kekuatan Fisik dan Intelektual Penuh - Perkembangan Intelektual Lengkap (Dari 33-40 tahun)

Banyak ayat yang mendukung tahap ini seperti 6: 152, 12:22, 17:36; 22: 5; 28:14; 40:67; dan 46:14 yang khususnya memberikan bukti paling mencolok tentang ini. Bunyinya sebagian sebagai berikut:

Dan tatkala dia cukup dewasa Kami berikan kepadanya hikmah dan ilmu. Demikianlah Kami memberi balasan kepada orang-orang yang berbuat baik (Yusuf: 22).

Karena itu jelas dari ayat ini bahwa pada usia 40 tahun, orang normal biasanya 
mencapai puncak perkembangan intelektualnya.

Tahap Tujuh: Periode Keteguhan dalam Perkembangan Kognitif (Dari $40-60$ tahun)

Meskipun penurunan fungsi kognitif diasumsikan biasanya mulai terjadi setelah 40 tahun, bahkan jika itu terjadi, sangat halus dan sulit diamati atau terlihat. Itulah sebabnya beberapa ahli menyebut tahap ini sebagai Sinnul-Tawaqquf, yang berarti suatu tahap di mana tidak ada perkembangan progresif lebih lanjut dari fungsi mental yang dapat dikenali atau penurunan itu sendiri. Lebih baik disebut usia keteguhan dalam perkembangan mental. Tetapi jelas bahwa fungsi mental seseorang tetap tampak normal dalam tahap ini. Dasar dari pernyataan ini adalah Hadis dimana Nabi (SAW) menafsirkan ayat 37 dari Surah Fathir.

Dan mereka berteriak di dalam neraka itu : "Ya Tuhan kami, keluarkanlah kami niscaya kami akan mengerjakan amal yang saleh berlainan dengan yang telah kami kerjakan." Dan apakah Kami tidak memanjangkan umurmu dalam masa yang cukup untuk berfikir bagi orang yang mau berfikir, dan (apakah tidak) datang kepada kamu pemberi peringatan? maka rasakanlah (azab Kami) dan tidak ada bagi orang-orang yang zalim seorang penolongpun.

\section{Tahap Delapan: Zaman Tua (Dari 60-80 tahun)}

Pada tahap inilah penurunan fungsi mental yang bertahap dan mulai menjadi jelas. Dalam ayat 67 dari Suratu-Ghafir, Allah berfirman

Dia-lah yang menciptakan kamu dari tanah kemudian dari setetes mani, sesudah itu dari segumpal darah, kemudian dilahirkannya kamu sebagai seorang anak, kemudian (kamu dibiarkan hidup) supaya kamu sampai kepada masa (dewasa), kemudian (dibiarkan kamu hidup lagi) sampai tua, di antara kamu ada yang diwafatkan sebelum itu. (Kami perbuat demikian) supaya kamu sampai kepada ajal yang ditentukan dan supaya kamu memahami (nya).

Tahap Sembilan: Usia Tua atau Indra yang semakin lemah) (Dari 80 tahun ke atas)

Ini kadang-kadang dimulai setelah delapan puluh tahun; itu adalah periode di mana kemunduran mental menjadi jauh lebih jelas terutama ketika usia meningkat menuju 100 tahun ke atas. Banyak ayat Al-Qur'an yang merujuk pada tahap perkembangan kognitif ini. Misalnya: 16:70 dan 22: 5. Nabi Muhammad (SAW) biasa mencari perlindungan dengan Allah agar tidak hidup sampai tahap kehidupan ini. 
Dari Anas bin Malik ia berkata, "Rasulullah shallallahu 'alaihi wa sallam bersabda, "Ya Allah, sesungguhnya aku berlindung kepada-Mu dari kelemahan, kemalasan, sifat pengecut, pikun, bakhil, dan aku berlindung kepada-Mu dari azab kubur dan fitnah hidup dan mati."

Dari Sa'ad bin Abi Waqqash radhiyallahu 'anhu bahwa Rasulullah shallallahu 'alaihi wa sallam meminta perlindungan di akhir shalat dengan kalimatkalimat ini, (Artinya: Ya Allah, aku berlindung kepada-Mu dari sifat pengecut dan kikir, dan aku berlindung kepada-Mu dari dikembalikan kepada umur yang paling hina (kepikunan), aku berlindung kepada-Mu dari fitnah dunia, dan aku berlindung kepadaMu dari fitnah kubur).” (HR. Bukhari)

\section{Konsep Kehidupan di Era Revolusi 4.0}

Dalam karyanya yang berjudul "Industri 4.0" (Lasi et al., 2014) menggambarkan proyek masa depan yang dapat didefinisikan oleh dua arah pengembangan. Di satu sisi ada tarikan aplikasi besar, yang menginduksi kebutuhan yang luar biasa untuk perubahan karena kondisi kerangka kerja yang berubah. Pemicu untuk ini adalah perubahan sosial, ekonomi, dan politik secara umum. Mereka khususnya:
Periode pengembangan singkat: Periode pengembangan dan periode inovasi perlu dipersingkat. Kemampuan inovasi yang tinggi menjadi faktor penentu keberhasilan bagi banyak perusahaan ("waktu ke pasar").

Individualisasi sesuai permintaan: Perubahan dari penjual menjadi pasar pembeli telah terlihat jelas selama beberapa dekade sekarang, yang berarti pembeli dapat menentukan kondisi perdagangan. Tren ini mengarah ke peningkatan individualisasi produk dan kasus ekstrem ke produk individu. Ini juga disebut "ukuran batch satu".

Fleksibilitas: Karena persyaratan kerangka kerja baru, fleksibilitas yang lebih tinggi dalam pengembangan produk, terutama dalam produksi sangat diperlukan.

Desentralisasi: Untuk mengatasi kondisi yang ditentukan ini, diperlukan prosedur pengambilan keputusan yang lebih cepat. Untuk selanjutnya, hierarki organisasi perlu dikurangi.

Efisiensi sumber daya: Meningkatnya kekurangan dan peningkatan harga terkait sumber daya serta perubahan sosial dalam konteks aspek-aspek biologis membutuhkan fokus yang lebih intensif pada keberlanjutan 
dalam konteks industri. Tujuannya adalah peningkatan efisiensi secara ekonomi dan ekologis.

Namun, terkait pekerjaan, terutama dalam konteks industri, teknologi inovatif tidak tersebar luas. Oleh karena itu, (Lasi et al., 2014) menjelaskan dorongan teknologi yang luas dapat diidentifikasi menjadi:

\section{Mekanisasi dan otomatisasi yang semakin meningkat: Dalam proses kerja akan} semakin banyak bantuan teknis yang akan digunakan, yang mendukung pekerjaan fisik. Selain itu, solusi otomatis akan mengadopsi pelaksanaan operasi serbaguna, yang terdiri dari komponen operasional, dispositif, dan analitik seperti sel manufaktur "otonom" yang secara independen mengontrol dan mengoptimalkan manufaktur dalam berbagai langkah.

Digitalisasi dan jaringan: Meningkatnya digitalisasi semua manufaktur dan alat pendukung manufaktur menghasilkan pendaftaran jumlah aktor-dan-sensor data yang meningkat yang dapat mendukung fungsi kontrol dan analisis. Proses digital berkembang sebagai hasil dari peningkatan jaringan komponen teknis dan, bersamaan dengan peningkatan digitalisasi barang dan jasa yang diproduksi, mereka mengarah ke lingkungan yang sepenuhnya digital. Mereka pada gilirannya mendorong kekuatan untuk teknologi baru seperti simulasi, perlindungan digital atau resp virtual seperti augmented reality.

Miniaturisasi: Secara bersamaan ada kecenderungan menuju miniaturisasi. Saat komputer membutuhkan ruang yang signifikan beberapa tahun yang lalu, saat ini perangkat dengan kinerja yang sebanding atau bahkan jauh lebih baik dapat diinstal pada beberapa besaran sentimeter kubik. Ini memungkinkan bidang aplikasi baru, terutama dalam konteks produksi dan logistik.

Lasi et al., (2014) menyatakan bahwa istilah Industry 4.0 secara kolektif mengacu pada berbagai konsep saat ini, yang diklasifikasi dengan jelas mengenai suatu disiplin. Ia menyarankan konsep-konsep dasar sebagai berikut:

Smart Factory: Pabrik sepenuhnya akan dilengkapi dengan sensor, aktor, dan sistem otonom. Dengan menggunakan "teknologi pintar" yang terkait dengan model produk dan pabrik yang terdigitalkan secara digital (pabrik digital) dan penerapan berbagai teknologi Komputasi Ubiquitous, yang disebut "Pabrik Pintar" berkembang yang 
dikendalikan secara otonom (Lucke, Constantinescu, \& Westkämper, 2008).

\section{Sistem Cyber-physical: Penggabungan} level fisik dan digital. ini mencakup tingkat produksi serta produk, sistem muncul yang representasi fisik dan digitalnya tidak dapat dibedakan dengan cara yang masuk akal lagi.

Organisasi mandiri: Sistem manufaktur yang ada semakin terdesentralisasi. Ini muncul bersamaan dengan dekomposisi hirarki produksi klasik dan perubahan ke arah swasusun yang terdesentralisasi.

Sistem baru dalam distribusi dan pengadaan: Distribusi dan pengadaan akan semakin individual. Proses yang terhubung akan ditangani dengan menggunakan berbagai saluran yang berbeda.

\section{Sistem baru dalam pengembangan produk}

dan layanan: Pengembangan produk dan layanan akan disesuaikan dengan kebutuhan masing-masing. Dalam konteks ini, pendekatan inovasi terbuka dan intelijen produk serta ingatan produk sangat penting.

\section{Adaptasi dengan kebutuhan manusia:}

Sistem manufaktur baru harus dirancang untuk mengikuti kebutuhan manusia, bukan sebaliknya.

\section{Tanggung Jawab Sosial Perusahaan:} Keberlanjutan dan efisiensi sumber daya semakin menjadi fokus dalam desain proses manufaktur industri. Faktor-faktor ini adalah kondisi kerangka dasar untuk produk yang berhasil.

\section{PEMBAHASAN}

Berdasarkan studi literature, diperoleh bahwa terdapat lima (5) model bioekologi dari perkembangan manusi menurut Urie Bronfenbrenner meliputi mikrosistem, mesosistem, eksosistem, makrosistem, dan kronosistem. Selain itu ditemukan pula Sembilan (9) tahapan perkembangan manusia dari perskpektif islam. Untuk kehidupan di era revolusi indsutri 4.0 yang lebih mengedepankan internet dan fleksibelitas dalam kehidupan.

Ditinjau dari tahap mikrosistem, anak hanya dipengaruhi oleh satu lingkungan di sekitar mereka. Dalam pandangan islam maka ini terletak pada tahap pertama $(0-2$ tahun), pada tahap ini anak baru memperoleh perspeksi sensorik, sehingga belm boleh menerima paparan dunia internet di era revolusi 4.0. Dalam tahap mesosystem, dikatakan ada lebih dari satu system yang mempengaruhi perkembangan anak misalnya pengaruh teman dan orangtua secara similtan 
terhadap motivasi anak. Di tahap ini jika ditinjau secara Islam sudah masuk pada tahap kedua hingga ke empat. Namun, jika ingin dilibatkan pada pemenuhan kebutuhan di industri 4.0 masih harus disesuaikan lagi. Sebab, pada tahap ke 2 (2 -7 th) anak baru pertama kali mengenal apa arti tugas dan kewajiban. Sehingga masih perlu dibimbing untuk melintasi era revolusi 4.0 dengan karakter digitalisasinya.

Tahap eksosistem oleh Urie Brofenbrenner menjelaskan bahwa ada faktor eksternal dari luar lingkungan anak yang secara tidak langsung berpengaruh terhadap perkembangan anak. Misalnya lingkungan kerja orang tua yang menyebabkan mereka stress saat bekerja. Sikap stress ini kemudian di bawa pulang dan dilampiaskan ke anak. Tentu ini akan mempengaruhi perkembangan anak. Dalam Islam tahap ini juga sangat rentang di periode 2 hingga 4 . Sementara itu di era revolusi industri di mana semua mulai bersifat desentralisasi atau diatur secara skala kecil. Membuat anak dapat menolak atau melawan ketika menjadi tempat pelampiasan orang tua. Di tahap makrosistem, ada faktor luar yang secara langsung bersinggungan dengan perkembangan. Misalnya kebijakan pemerintah. Dalam kebijakan ini akan benarbenar dirasakan oleh orang dewasa, dalam
Islam pada tahap kelima hingga ketujuh. Di mana pada tahap ini mereka mulai dari tahap pematangan mental hingga matang sempurna. Di tahap inilah seorang anak manusia sudah mampu beradaptasi dengan perkembangan era revolusi industri yang sangat cepat, adaptasi kebutuhan manusia, organisasi digital dan hal lain yang membutuhkan kematangan mental.

Tahap terakhir dari perkembangan menurut model bioekologikal adalah kronosistem. Pada tahap ini, perkembangan anak dipengaruhi oleh perbuahan zaman. Sebagai contoh perbedaan budaya dari anak generasi millennial dan gernerasi Z. Pada tahap ini dalam islam seseorang yang sudah berada di usia tua akan melihat perbedaan yang sangat jelas semasa hidupnya. Di mana kondisi yang diraskan terasa sangat berbeda dengan saat di masih muda dulu. Dalam perkembangan teknologi selanjutny di era revolusi ke sekian akan menentukan bagaimana manusia dapat berkembang dengan cepat. Meskipun begitu mereka harus selalu memperhatikan nilai-nilai Islam untuk memperoleh ketenangan hidup selamanya.

\section{PENUTUP}

Terdapat semibilan (9) tahap perkembangan kognitif manusia dalam 
perspektif Islam dari usia 0 th -80 th ke atas.

Ada lima (5) tahap perkembangan berdasarkan model bioekologikal Urie Bronfenrebrenner mikrosistem, mesosistem, eksosistem, makrosistem, dan kronosistem. Ada banyak prinsip dasar dalam kehidupan di era revolusi 4.0 meliputi fleksibilitas, efisiensi, digitalisasi, desentralisasi, dan individualisasi kebutuhan. Kesemuanya saling mempengaruhi kehidupan manusia di era 4.0

\section{REFERENSI}

Abdullah, F. (2012). The role of Islam in human capital development: A juristic analysis. Humanomics. https://doi.org/10.1108/0828866121120 0997

Ahmad, N., Bhatti, K. A., \& Arshad, M. U. (2013). Economic Growth and Human Development in Islam. Al Qolam Journal.

Al-Qaradawi, Y. (1985). The Iman (Faith) and Life. Doha: Arabia Publication.

Alkire, S. (2002). Dimensions of human development. World Development, 30(2), 181-205. UK: Elsevier Science. Baumrind, D. (1989). Rearing competent children. In W. Damon (Ed.), Child development today and tomorrow (pp. 349-378). San Francisco, CA: Jossey-Bass.

Ashiabi, G., \& O’Neal, K. (2015). Child Social Development in Context: An Examination of Some Propositions in Bronfenbrenner's Bioecological Theory. SAGE Open. https://doi.org/10.1177/2158244015590 840
Bronfenbrenner, U. (1979). The ecology of human development: Experiments by nature and design. Cambridge, MA: Harvard University Press.

Bronfenbrenner, U. (1994). Nature-Nurture reconceptualized in developmental perspective: A bioecological model. Psychological Review, 101(4), 568-86.

Bronfenbrenner, U. (1995). Developmental ecology through space and time: A future perspective. In P. Moen, G. Elder, \& K. Lusher (Eds.), Examining lives in context: Perspectives on the ecology of human development (pp. 619-647). Washington, DC: American Psychological Association.

Bronfenbrenner, U., \& Morris, P. A. (2006).

The biological model of human development. In W. Damon \& R. M. Lerner (Eds.), Handbook of child psychology: Theoretical models of human development (6th ed., Vol. 1, pp. 793-828). New York, NY: Wiley.

Carter, P. (2007). Keeping it real: School success beyond black and white. New York, NY: Oxford University Press. Conger, R., K. Conger, \& Martin, M. (2010). Socioeconomic status, family processes, and individual development. Journal of Marriage and Family, 72, 685-704

Gorecky, D., Schmitt, M., Loskyll, M., \& Zühlke, D. (2014). Human-machineinteraction in the industry 4.0 era. In Proceedings - 2014 12th IEEE International Conference on Industrial Informatics, INDIN 2014. https://doi.org/10.1109/INDIN.2014.69 45523

Hassi, A. (2012). Islamic perspectives on training and professional development. Journal of Management Development. https://doi.org/10.1108/0262171121128 1816 
Hermann, M., Pentek, T., \& Otto, B. (2016).

Design principles for industrie 4.0 scenarios. In Proceedings of the Annual Hawaii International Conference on System Sciences. https://doi.org/10.1109/HICSS.2016.48 8

Keller, M., Rosenberg, M., Brettel, M., \& Friederichsen, N. (2014). How Virtualization, Decentrazliation and Network Building Change the Manufacturing Landscape: An Industry 4.0 Perspective. International Journal of Mechanical, Aerospace, Industrial, Mechatronic and Manufacturing Engineering.

Lasi, H., Fettke, P., Kemper, H. G., Feld, T., \& Hoffmann, M. (2014). Industry 4.0. Business and Information Systems Engineering. https://doi.org/10.1007/s12599-0140334-4

Lee, O., \& Martinek, T. (2013). Understanding the Transfer of ValuesBased Youth Sport Program Goals From a Bioecological Perspective. Quest. https://doi.org/10.1080/00336297.2013. 791871

Lucke, D., Constantinescu, C., \& Westkämper, E. (2008). Smart Factory - A Step towards the Next Generation of Manufacturing. In Manufacturing Systems and Technologies for the New Frontier. https://doi.org/10.1007/978-184800-267-8_23

Morales, H., da Agra, C., \& Matsuno, M. (2019). Antisocial Behavior in Juvenile Offenders: A Development Bioecological Approach*. Journal of Prevention and Intervention in the Community. https://doi.org/10.1080/10852352.2019. 1664712

O’Toole, L., Hayes, N., \& Halpenny, A. M. (2019). Animating Systems: The ecological value of Bronfenbrenner's bioecological model of development. In Ecologies for Learning and Practice (pp. 19-31). Routledge.

Razimi, M. S. B. A., Noor, M. M., \& Daud, N. M. (2014). The concept of dimension in human resource management from Islamic management perspective. Middle - East Journal of Scientific Research. https://doi.org/10.5829/idosi.mejsr.201 4.20.09.12513

Rosa, E. M., \& Tudge, J. (2013). Urie Bronfenbrenner's Theory of Human Development: Its Evolution From Ecology to Bioecology. Journal of Family Theory \& Review. https://doi.org/10.1111/jftr.12022

Shehu, S. (2015). A Study of the Islamic Perspective of Cognitive Development and Its Implications in Education in the Muslim World. Revelation and Science, 5(1).

Shokhibul Arifin. (2016). Perkembangan Kognitif Manusia Dalam Perspektif Psikologi Dan Islam. Tadarus :Jurnal UM Surabaya.

Sivathanu, B., \& Pillai, R. (2018). Smart HR 4.0 - how industry 4.0 is disrupting HR. Human Resource Management International Digest. https://doi.org/10.1108/HRMID-042018-0059 